\title{
Communication
}

\section{Worker 4.0: The Future of Sensored Construction Sites}

\author{
Diego Calvetti ${ }^{1}$ (D) Pedro Mêda ${ }^{2, *}$, Miguel Chichorro Gonçalves ${ }^{1}$ and Hipólito Sousa ${ }^{1}$ (i) \\ 1 CONSTRUCT/GEQUALTEC, Faculty of Engineering, Porto University, 4200-465 Porto, Portugal; \\ diego.calvetti@prodyoup.com (D.C.); miguelcg@fe.up.pt (M.C.G.); hipolito@fe.up.pt (H.S.) \\ 2 CONSTRUCT/GEQUALTEC, Construction Institute, Faculty of Engineering, Porto University, \\ 4200-465 Porto, Portugal \\ * Correspondence: pmeda@fe.up.pt
}

Received: 18 August 2020; Accepted: 21 September 2020; Published: 23 September 2020

\begin{abstract}
The digitalization of the construction industry (CI) has the aim-among others-to raise the bar of overall productivity. The craft workforce is very relevant on the overall value-chain. Therefore, a boost in this dimension impacts the entire sector. There is a gap in proper methodologies to measure and model productivity. Construction 4.0 novelties provide new approaches for its evaluation and progress. This communication presents a review of workforce productivity assessment and delivers methods focusing primarily on craft workers motion monitoring. Products and services opportunities from Construction 4.0 in the spectrum of craft workforce management include support by embedded sensors for data collection that allow near real-time monitoring. The work developed led to the systematization of a framework to standardize craft workers' motion productivity. The craft workforce motion productivity framework, Worker 4.0, tenders nine processes integrated on a flowchart to streamline task processes assessment and mechanization level. It also sets up a two-handed/two-legged chart system to model craft workers' activities and operations. The contributions to the body of knowledge are substantiated on the framework creation with the ability to model and assess craft workforce performance. This approach is meant to serve as base point for different stakeholders focusing on skills, efficiency, mechanization and productivity improvements.
\end{abstract}

Keywords: workforce; productivity; construction 4.0; sensing technologies; electronic performance monitoring; therblig; processes improvement; tasks operation modeling

\section{Introduction}

The Industry 4.0 concept aims at complete information (IoT) for digitalization and works automation. In the context of the construction industry (CI), task processes remain strongly linked to the craft workforce. At the European Union level, construction "crafts and trade workers" represents $56 \%$ of sector' employment [1].

The systematic control of construction operations brings immediate awareness of the activities under development specific aspects to provide the needed information for decision-making within an agile management environment [2]. Current technological advances enable new methods of data collection that increase reliability and real-time information. In addition, recent innovations in micro and nanotechnology foster perennial assessments of each worker's task performance on-site.

Since Frank and Lillian Gilbreth's research, work design and motion studies have been developed following different approaches for modeling/measuring productivity, mainly through human observation of field activities [3-5]. A micromotion analysis [4], can be described as an in-depth study on geo-localizations, actions, movements and gestures. Nonetheless, current technological advances foster the automation of some manual data collection processes.

New procedures for analysis focus on the geographical mapping of worker locations and trajectories in order to quantify the time spent in specific work areas [6,7]. Other studies seek a detailed 
analysis of workers' movements and gestures using the skeleton vectoring method [8,9]. Furthermore, the current technological development has strengthened the provision of wearable devices equipped with sensors to analyze the physiological aspects of individuals $[10,11]$. Finally, in the era of global pandemic diseases, sensor monitoring can help with protective actions as social distancing rules in construction sites [12].

A built object takes shape during the manufacturing and construction phase [13]—through a succession of tasks involving construction products, equipment (and construction aid) and human labor, namely craft workforce physical and mental effort. In this respect, some tasks can be developed only with human strength and technical skills or can be supported (efforts attenuated in some cases) with the use of hand tools (e.g., wrenches, hacksaws, trowels) [4], portable power tools (e.g., drills, circular saws, routing tools) or other accessories.

In other cases, the workforce can operate machines/equipment (e.g., cranes, backhoes, walk-behind vibratory-plate compactors). In all these situations, construction products are involved as a construction resource that is transported, assembled or transformed and placed on site to lead or to be part of a construction element or system [14-16].

Within the current construction framework, the presence of operators is still required-even in activities with a high degree of mechanization [15]. In fact, craft workforce performance is the primary productive factor in the construction industry [15]. As aforementioned, construction tasks are based on worker-handled or worker-machines systems. Few processes are based on automated systems [4]. Figure 1 frames the concept of construction tasks core-based on craft workers (handling tools), equipment/machines and products.

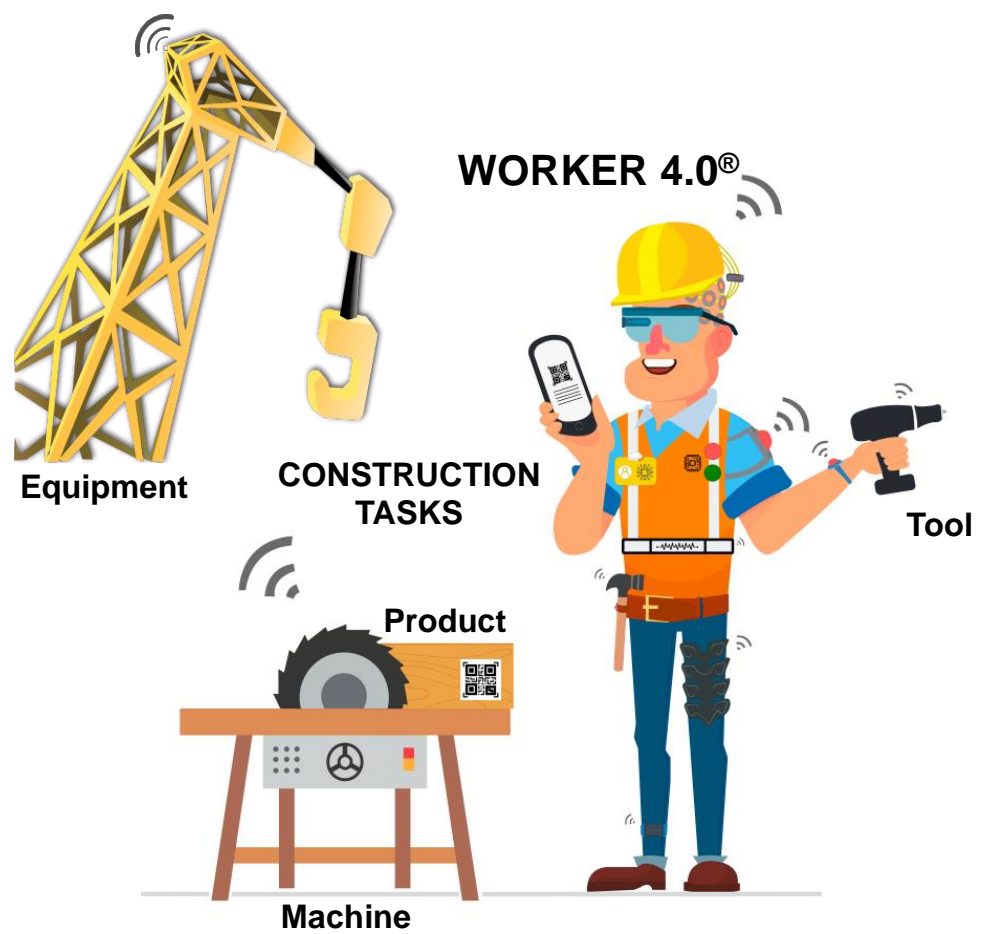

Figure 1. Construction tasks: workers + products + equipment.

Productivity assessment to increase the performance of projects is not a one-off task [17]. Although several studies had investigated construction craft workforce productivity [18-31], very few of them focus on the tasks processes modeling. Consequently, this work can contribute to the current body of knowledge in the CI productivity challenges. The present research frames within Construction 4.0 goals and aims to investigate the concept and the assessment of productivity in the $\mathrm{CI}$, in order to foresee a craft workforce systematic process of electronic performance monitoring using sensing technology. 


\section{Sensored Construction Sites}

According to Qi et al. [32], the construction industry is currently applying and in a near future will add investments on three top technologies: BIM dimensions analysis models; sensing technology and business information models. This highlights the relevance of methodologies based on sensing techniques and models to deliver outcomes for improved business.

There is a broad range of sensors and sensing solutions and in the forthcoming years it is expected that this already broad market will become bigger. What is sought to monitor, the monitoring sample size (number of workers/professionals), the construction company project field (e.g., buildings, infrastructures, both, service providers) and the type of solutions available are essential aspects to consider before starting an implementation process. The combination of different types of technologies can cover the monitoring of more diverse aspects with a higher cost-benefit [15]. Sensing technologies implementation processes can be highly complex and may require specialized resources. Project managers should increase their competencies on innovativeness and communication [33] to better address on-site project innovations. To seek higher success rates in $\mathrm{CI}$ sensors application, electronic data collection devices must meet many of criteria, such as return on investment (ROI); resistance and durability; energy capacity/independence; ergonomic sizes and weights; user-friendly; scalability; reliability; high-frequency data rate; smaller specific communication infrastructure possible, smaller data volume for possible storage; data security [34].

Figure 2 presents the many sensors (embedded on devices/equipment/tags) to monitor construction sites activities. The hardware devices/equipment can bring embedded more than one type of sensor (e.g., smartphones, smartwatches, cranes, etc.). Also, the workers themselves on-duty operating equipment/machine or handling tools/products are physical elements. For data communication, an essential physical infrastructure of different types of equipment is needed to transmit, store and process data (e.g., modems, gateways, bridge). The data can flow between devices and equipment, for example, through Wi-Fi or Bluetooth. Finally, information connectivity will be mainly assured via Ethernet for IoT platforms on local or cloud data storage. Associated with devices and equipment are the native systems (embedded software) for their operation. Different systems (interface software) are needed to store and process data such as operating systems and databases. Throughout the process of implementing the devices, their use, data collection and processing, various actors/knowledge is required.

Portable devices are considered those that are handled by workers. On the other hand, wearable devices can be inferred as those that are next to the body, that is, adhered or in clothes [35] and also as those coupled to personal protective equipment of workers [10,36-38]. First, because they are close to the human body, these technologies must be provided with adequate anatomy and safety, for example, to avoid electric shocks or burns [35]. Other important issues are: esthetics, size, resistance to bad weather and aggressive environments, energy consumption, wireless communication and usability regarding the operating system used [35].

Consistent image tracking of multiple workers and equipment over a long period of time tends to be more problematic [7]. Imaging shows frequent failures due to obstacles and the trajectory crossing with dynamic elements [7]. The progress of the work performed by image systematics can be supplied with images collected by drones $[39,40]$. Three-dimensional images can be captured employing motion capture systems (e.g., VICON and MS-Kinect), 3D camcorders [41] and point-cloud devices [40]. These technologies are applied in the construction industry to monitor workers [8,41-43], equipment and workers [44] and the physical progress of the project construction tasks [45-47].

Within the scope of the construction industry, automated control of tools, machines and equipment can be established to verify their use. Moreover, and by inference, it can determine the time and the volume of work performed by the worker. As an example, rigging equipment has ohmmeters, and welding machines can be equipped with systems to control the amount of solder deposited. Moreover, it is possible to control the environmental factors at the construction site utilizing various 
sensors, in order to monitor the environmental conditions as humidity, temperature, pressure, noise, luminance and rainfall indices, among others.

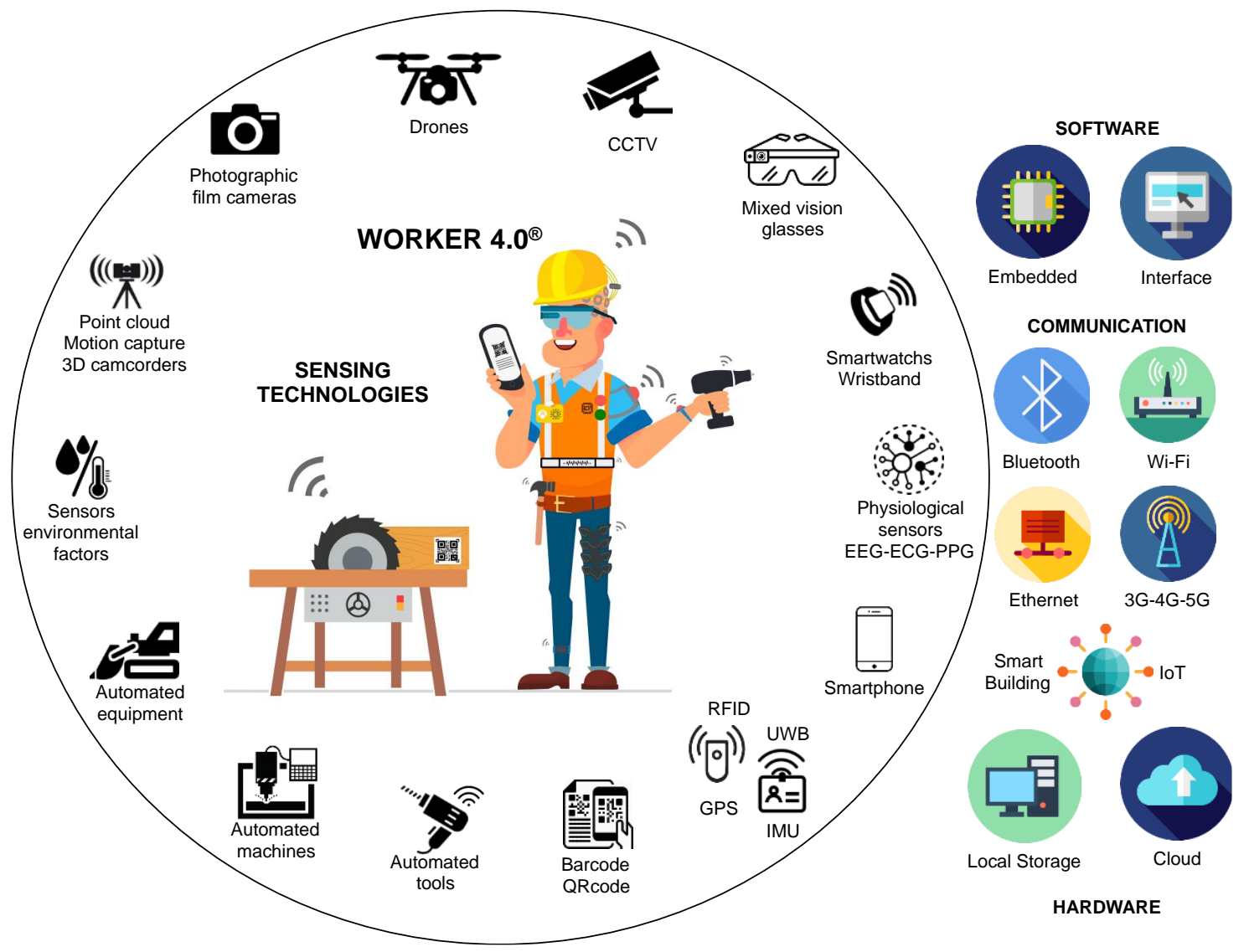

Figure 2. Worker 4.0: Sensored construction sites.

A possible clustering based on the use/format of these sensor technologies is following presented connected with academic research or commercial references:

Portable or Wearable

- $\quad$ RFID (radio-frequency identification), tags/devices [48-52];

- UWB (ultra-wide-band), tags/devices [53-58];

- $\quad$ GPS (global positioning system), tags/devices [59-63];

- IMU (inertial measurement unit), tags/devices [36,37,64,65];

- $\quad$ Barcode/ QR code, labels or passive tags [66,67];

- Smartphones, devices [20,38].

Wearable Devices

- Physiological sensors (e.g., electroencephalogram [10,68], electrocardiogram [36,69], photoplethysmography $[70,71])$;

- Smartwatches [11] and wristbands [69-71];

- Mixed vision glasses (e.g., Google Glass [72] and Microsoft HoloLens [73]);

- Quality life and Sports wearables (e.g., Athos—sportswear that monitors muscular effort [74], Motiv—ring that monitors body movements and activities [75], Nuada—electronic glove for increased motor power [76]). 
Image devices

- 2D images (e.g., CCTV systems, photographic and film cameras) [77-82];

- 2 D images (e.g., drones-UAVs, unmanned aerial vehicles) [83,84];

- 3 D images (e.g., point cloud, motion capture systems, 3D camcorders) [8,41-44].

Automated Systems (sensor embedded)

- $\quad$ Sensored tools (e.g., torque wrench) [85];

- $\quad$ Sensored machines (e.g., welder machines) [86];

- $\quad$ Sensored equipment (e.g., cranes) [87].

Miscellaneous Sensor Devices

- External sensors for measuring environmental factors (e.g., temperature, humidity, noise) [88].

Figure 3 presents the workers/environment conditions (features) that can be monitored by sensoring technologies. This human data generated will allow the development of new methods to assess workers vital factors as skills, motivation and fatigue. Finally, that knowledge can be used to influence actions on workforce training to increase on-site safety and productivity.

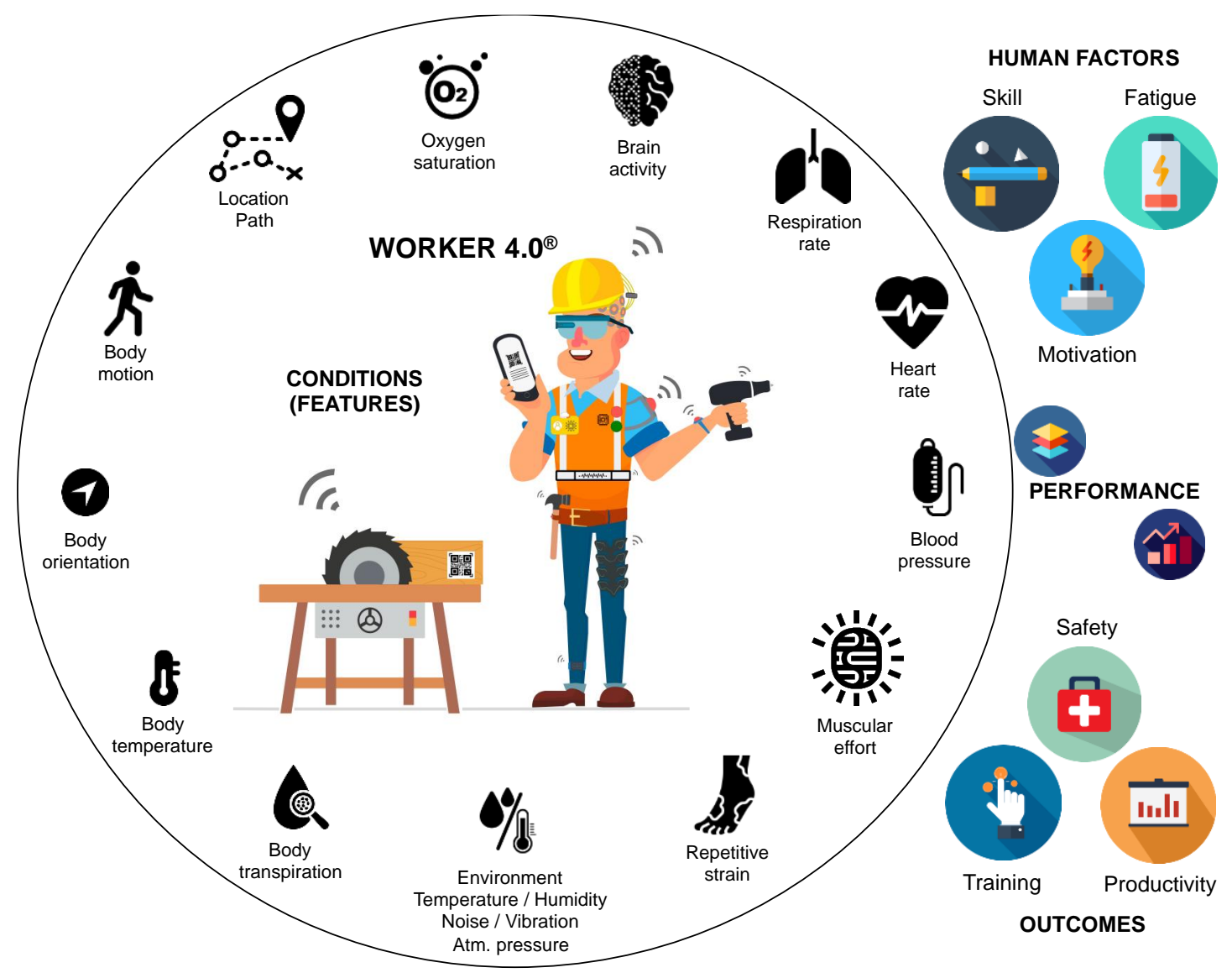

Figure 3. Worker 4.0: Human data generated.

The fatigue of construction workers is directly related to nonproductivity, loss of services quality and increased risk of accidents [10]. The physiological aspects of the workers can be monitored, according to the parameter and type of sensor to be used, for example, electrocardiogram (electrodes); heart rate (electrodes or pulse oximeter); breathing rate (piezoelectric or piezoresistive sensor); 
body temperature (adhesive sensor); movement of the body (accelerometers); body orientation (accelerometers); oxygen saturation (pulse oximeter); sweat (galvanic response sensor); electromyogram (electrodes) [89]. Knowledge of these aspects is essential both for safety initiatives and also for worker productivity factors improved understanding [89].

The current technological development has strengthened the provision of wearable devices equipped with sensors to analyze the physiological aspects of individuals, mainly focusing on health and sports performance. Scientific studies present the application of commercial devices for the evaluation of workers in the construction industry $[10,11,69,70,72]$. Likewise, the use of more complex devices such as electroencephalograms (EEG) to measure the brain activity $[10,68]$ or to evaluate workers actions/conduct/behavior. Craft workers are the CI "athletes" and the researchers should apply all knowledge available to achieve their highest performance.

Through the use of images it becomes possible to map the trajectory and the occupation of workers and equipment, as well as to determine time spent in each cycle of the production process [7]. Electronic devices equipped with a battery or power supply and with a combination of types of sensors, as accelerometers, gyroscopes and even magnetometers, can determine workers body velocity, orientation and gravitational forces [90]. The body motion monitoring can foster diagnoses of inappropriate postures of construction workers during their manual activities [64]. Likewise, the skeletonization of the human body, with many sensors applied in joints and in specifics members (e.g., wrists and ankles) or according with the model of rotational matrices and Euler angles [65].

For human activity classification, the hardware, sensor-based acceleration, must be embedded on the worker, through wearable sensing technologies. Most importantly, for construction sites/real-life applications, this hardware should be adequate to wear without interferences (e.g., wireless, weightless). Smartphones $[18,19,23,24,91]$, wearables devices (e.g., inertial measurement units (IMU) $[25,26,92]$ and sports watches $[27,28]$ have been applied as leading hardware for human activity classification.

Hardware for activity classification may be composed by many components as accelerometers, magnetometer, gyroscope, Bluetooth, Wi-Fi, memory, battery, GPS and sensors of light and temperature. The combination of sensors, e.g., accelerometers, magnetometer, gyroscope [26] increases the processing accuracy, but at the same time, increases the hardware cost. The same dilemma is also placed in terms of the number of devices to cover the human body. A hardware solution based only on accelerometer will be more cost-efficient, and few devices offer a solution with a lower cost. Table 1 presents conducted studies on craft workforce productivity, focusing on sensors placement schema and monitored body movements. As highlighted in Table 2, scientific studies on activity classification have been focusing on different patterns of processes, tasks or motions. In the future, the added value of this study is to establish a framework for craft workforce motion productivity.

Table 1. Sensor-based studies conducted for activity classification.

\begin{tabular}{cccc}
\hline \multirow{3}{*}{ Sensors } & Characteristic & Number of Papers & References \\
& Accelerometer & 4 & {$[24,27,28,30,93]$} \\
& Accelerometer and gyroscope & 5 & {$[18-21,23]$} \\
& Accelerometer, gyroscope and magnetometer & 3 & {$[25,26,91]$} \\
\hline \multirow{3}{*}{ Movement of } & Arm & 5 & {$[18-21,25]$} \\
& Arms and waist & 2 & {$[29,30]$} \\
& All body & 4 & {$[24,26,91,93]$} \\
& Spine & 2 & {$[94,95]$} \\
& Wrist & 2 & {$[27,28]$} \\
\hline
\end{tabular}


Table 2. Studies conducted for different types of activity classification.

\begin{tabular}{ccr}
\hline Reference & Year & Classified Activity \\
\hline$[18]$ & 2016 & (1) Cut lumber; (2) transport (3) installation \\
\hline$[21]$ & 2018 & $\begin{array}{r}\text { Category 1 ((1) sawing against (2) idling); Category 2 ((3) hammer and } \\
\text { (4) turn a wrench against idling); Category 3 ((5) load sections into a } \\
\text { wheelbarrow, (6) push a loaded wheelbarrow, (7) dump sections from a } \\
\text { wheelbarrow and (8) return an empty wheelbarrow against idling) }\end{array}$ \\
\hline$[23]$ & 2018 & $\begin{array}{c}\text { (1) Stand, (2) walk, (3) squat, (4) clean up the template, (5) fetch and } \\
\text { place rebar, (6) locate the rebar, (7) bind rebar,(8) place concrete pads }\end{array}$ \\
\hline$[25]$ & 2018 & $\begin{array}{r}\text { (1) Grab tool/part, (2) hammer nail, (3) use power screwdriver, (4) rest } \\
\text { arm, (5) turn screwdriver and (6) use wrench }\end{array}$ \\
\hline$[28]$ & 2019 & $\begin{array}{r}\text { (1) Spread mortar; (2) bring and lay blocks; (3) adjust blocks; and (4) } \\
\text { remove remaining mortar }\end{array}$ \\
\hline$[30]$ & 2014 & (1) Effective work, (2) contributory work and (3) ineffective work \\
\hline$[31]$ & 2011 & (1) Fetch and spread mortar, (2) fetch and lay brick and (3) fill joints \\
\hline
\end{tabular}

\section{Productivity Assessment in the Construction Industry}

When determining the level for the evaluation of productivity, the possible analysis parameters are defined and, inherently, the type of requirements that can be analyzed. Yi and Chan (2014) introduced a four-level structure to analyze labor productivity in a top-down multilayer point-of-view [96]:

1. Nations/countries;

2. Industry (construction);

3. Project;

4. Activity/tasks.

The approach for evaluating labor performance is entirely different, depending on the analysis level. Yi and Chan [96] indicate a macroscopic spectrum for the analysis of the CLP (construction labor productivity) at a country level, considering a microscopic analysis at the activity level. El-Gohary and Abdel-Khalek [97] indicate that at project level, there is a micro level (project management and administration) and at the task level, there is a micro level. Finally, taking advantage of nanotechnology opportunities to monitor location, movements, acceleration of workers in on-site activities, this spectrum of analysis is completed with a "nanoscopic" dimension, allowing the assessment of work elements and basic motion elements.

In the late 1800s and early 1900s, the study of work elements by Frederick W. Taylor and the study of workers' basic motions by Frank Gilbreth represented the beginning of the work's structure microanalysis $[3,4,98]$. The basic motion elements are the instant movements (gestures that last less than a second) of the workers in service [4]. A work element is a performance, lasting six seconds or more, of multiple basic grouped movements that represent a function in a task (e.g., scraping, hammering, cutting) [4]. At least one task can be delivered in a few seconds or a few minutes, depending on the activity requirements [4].

Basic workers' motions methodologies as Therblig (reach, move, grasp, release, preposition, use, assemble, search, select, position, inspect, plan, unavoidable delay, avoidable delay, rest to overcome fatigue, hold) $[3,4,98]$ are relevant to industrial processes, but too much detail for its direct implementation in the CI.

Different approaches to the definition of a hierarchical level of labor productivity boundaries were developed. As an example: Area, activity and, task [99]; project, division, activity, task, elemental motion, orthopedics and, cell [100]; project, division, activity, basic task and, elemental motion [101] and; activity, task, action and, movement [102]. Throughout times, the CI seeks to increase its performance 
through tasks' mechanization [103]. Hwang et al. [103] developed a method to assess the level of mechanization in building construction projects containing five processes:

1. Completely manual;

2. Hand tool;

3. Automated hand tool;

4. Machine/workstation;

5. Completely automated.

\section{Craft-Workforce-Centered Method}

Based on the background, a proposal of a six multilevel pyramid to assess performance in both top-down and bottom-up approaches is presented in Figure 4. As a result, the pyramidal structure approach for performance assessment should differ depending on the stakeholder position. Countries for benchmark, as well as large corporations for decisions on transnational projects, should take a top-down approach. On the other hand, smaller companies with local businesses-or even large locally based construction companies-should take a bottom-up approach at tasks level to improve processes and increase the level of competition. Either way, both approaches end their analysis at the center of the pyramid (project and tasks), to diagnose, for example, the impact factors of productivity and to measure and develop on-site productivity metrics.

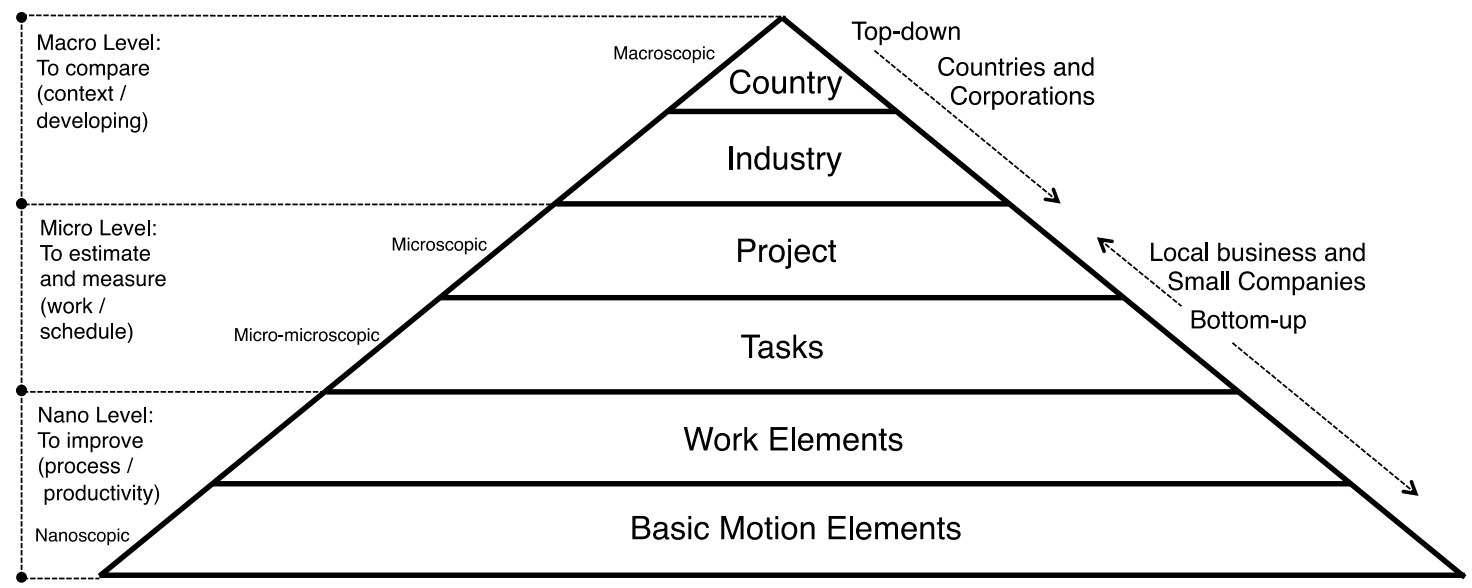

Figure 4. Approach levels to measure performance.

At the country level, the goal is to compare the productivity of the construction industry in each nation in order to identify benchmarking performances [104]. In this sense, generally, the economic dimension of performance is the most relevant. The assessment indicators are related to historical data of the sector's (GDP) gross domestic product (output) and, for example, the volume of man-hours employed (input).

At the industrial level, the economic aspect is still the most relevant to evaluate and benchmark labor productivity in an output-input ratio approach [105]. Further, it is tough to diagnose impact factors at industry levels accurately. This is related to variables such as management, labor, government, contracts, owner characteristics and financing [96]. Consequently, in order to have a deep understanding of the impact factors, it is necessary to carry out field analysis at project and task levels.

It is precisely at the project level that it is possible to identify where and when the construction takes place. At the task level, it is possible to measure the efficiency of the work methods through the conversion technology of inputs delivery and outputs measurable. Within the CI, it is valuable to obtain the income from the tasks, i.e., the number of resources (human, products and equipment) required to obtain a constructed item (e.g., a square meter of masonry or a cubic meter of concrete). 
Park and Tucker [106] emphasizes that benchmarking and metrics at the task level require the standardization of the measurement units for inputs and outputs. It is also at this level that the workflow is evaluated. Several models analyze the human, product and machinery resources within the productive cycles, mainly evaluating the sequence and interconnection of activities, the actions duration and standby states, as well as the amount of work performed.

Finally, at the bottom of the pyramid is the nano level of analysis. Basic motion elements and work elements are perceived, fostering a nano assessment of the craft workforce productivity.

It is through the physical and mental effort of direct labor that construction activities are performed. The physical and manual effort can be replaced or attenuated by the use of equipment, machines or power tools. However, within the current reality, even in activities with a high degree of mechanization, the intervention of a human operator is still necessary.

In this sense, the analysis of the workers' location, movement, gestures and even physiology (e.g., fatigue and degree of concentration), is highly relevant. Following the proposal at nano Level, it is possible to perform detailed analysis, capable of diagnosing the task processes and thus enable the understanding of processes technological conversion and inefficiencies diagnosis. Process improvement actions are essential tools to increase productivity. Worker 4.0 motion productivity focusing craft-workforce is established at nano Level.

Stating that the nano level is more prone to allow the increasing of the on-site productivity, a proposal for craft workforce motion productivity is presented. The craft workforce motion productivity framework, namely Worker 4.0 motion productivity, establishes nine processes to map and measure performance. Therefore, the nine processes are possible modeling any on-site building task, as presented in Table 3.

Table 3. Worker 4.0: motion productivity (W4MP).

\begin{tabular}{|c|c|c|}
\hline $\begin{array}{l}\text { Worker 4.0 Motion } \\
\text { Productivity }\end{array}$ & Group of Movements and Performance & Example \\
\hline Free-hand performing & $\begin{array}{l}\text { One or both hands during the tasks, handling } \\
\text { materials or products }\end{array}$ & putting a brick, etc. \\
\hline Auxiliary tools & $\begin{array}{l}\text { One or both hands during the tasks handling } \\
\text { auxiliary tools }\end{array}$ & using a spirit-level, etc. \\
\hline Manual tools & $\begin{array}{l}\text { One or both hands during the tasks handling manual } \\
\text { tools }\end{array}$ & using a trowel, etc. \\
\hline Electric/electronic tools & $\begin{array}{l}\text { One or both hands during the tasks, handling } \\
\text { electric/electronic tools }\end{array}$ & using a drill, etc. \\
\hline Machines operation & $\begin{array}{l}\text { One or both hands during the tasks, dealing with } \\
\text { machines/workstations or dealing with equipment }\end{array}$ & $\begin{array}{l}\text { using a bench circular } \\
\text { saw, using a backhoe, etc. }\end{array}$ \\
\hline Robotic automation & Automated work based on robotic equipment & $\begin{array}{l}\text { robotic bricklaying } \\
\text { arm, etc. }\end{array}$ \\
\hline Do not operate value & $\begin{array}{l}\text { Doing any productive work. That does not advance } \\
\text { the progress of the tasks. Furthermore, identified as } \\
\text { "ineffective Therbligs" or "not productive" }\end{array}$ & $\begin{array}{l}\text { planning, searching, } \\
\text { chatting, resting, human } \\
\text { needs, etc. }\end{array}$ \\
\hline Walking & Walking without carrying anything on hands & $\begin{array}{l}\text { going to the WC, } \\
\text { idleness, etc. }\end{array}$ \\
\hline Carrying & Walking carrying something on hands & $\begin{array}{l}\text { products, equipment, } \\
\text { tools, etc. }\end{array}$ \\
\hline
\end{tabular}

It is essential to highlight that manual data collection by direct observations is an ancient practice. Nevertheless, it is time-consuming, costly, labor-intensive and highly prone to failures [2]. Framing this practice with privacy issues, it is also relevant to emphasize that manual data collection relies on one person looking from close to others that are performing a task and taking notes from it. Furthermore, 
data post-evaluation models are more effective when the work process is routinely repeated [2]. In the case of $\mathrm{CI}$, where projects have higher non-repeatable work processes, post-data evaluation techniques have limited gains [2].

As above stated and into the opportunities for Construction 4.0 on sensing technologies, to fulfil the Worker 4.0 frameworks proposed, it is vital the implementation of electronic performance monitoring models. Given the large amount of data collected by electronic devices and, in order to process such information quickly and autonomously, it is necessary to use postprocessing based on machine intelligence. Academic studies focusing on the classification of human activities/actions develop algorithms based on deep learning $[25,107]$ and machine learning $[28,93,108]$.

\section{Worker 4.0}

\subsection{Motion Productivity}

This paper proposes mixing work elements and basic motion elements to enable the mapping process of all construction tasks, providing an adequate process to increase on-site production. The proposed production process modelling will allow the measurement of the amount of service performed (by hand or mechanized) in a similar method as recommended by Hwang et al. [103]. Likewise, assesses the unproductive and time spent in auxiliary activities. As presented in Section 2, previous academic studies applied diffuse techniques, not focusing on the modeling of production processes. This study precisely proposes the formation of a pattern with a focus on CI on-site tasks modeling.

In addition, it sets a common basis for the measurement of the energy expended (e.g., $\mathrm{kcal} / \mathrm{min}$, $\mathrm{Btu} / \mathrm{min}$ ) on each process. Table 4 presents the nine processes of craft workforce motion productivity and their acronyms detailing the:

- The element level of the tasks (work element or basic motion element) $[4,98]$ and autonomous when robotic automation;

- Processes characteristic (operation, inspection, delay, transportation/storage), processes meanings and symbols follow the same pattern of well-known process chart flow applied in macromotion studies [109];

- Productive state (productive or direct work, contributory or support work, nonproduction work) the productive state addresses the workforce performance during the development of tasks [110] and autonomous production in the case of automated robotic equipment;

- Electronic Monitoring (body motion, location, sound/noise), suggests an approach to monitor the performance employing electronic devices. Those three elements are considered the minor features to control and to measure the performance. Electronic monitoring more aspects than the ones indicated would provide more outputs, but as well, it would increase complexity and cost. It is possible to interpreter the activity being performed based on the hands and the legs motions when accomplishing all nine processes. Furthermore, monitoring image-based can identify that elements handling by the workers. At the same time, some activity processes, such as free-hand performing, auxiliary tools, manual tools, and electric/electronic tools can be captured just by the hands' motion. The legs contribute to this assessment and also provide more useful information for others (for example, do not operate value; walking; carrying). Therefore, it is considered appropriate to wear devices on wrists or arms and legs to, at least, capture that motion acceleration. Beyond this, the monitoring of workers' body rotation and location, if added, can increase the analysis. As an example, from monitoring the trajectory, it can make it possible to interpret the collection/carrying of elements from storage areas or machine/equipment movement. Furthermore, the sound/noise tracking of electric tools, machines and equipment can allow the identification of operating times and indicate the components-specific type. 
Table 4. Worker 4.0: motion productivity (W4MP) specifications and patterns.

\begin{tabular}{|c|c|c|c|c|c|c|}
\hline \multirow{2}{*}{$\begin{array}{l}\text { Worker 4.0 Motion } \\
\text { Productivity }\end{array}$} & \multirow{2}{*}{ Acronym } & \multirow{2}{*}{$\begin{array}{l}\text { Element Level } \\
\text { of the Tasks }\end{array}$} & \multicolumn{2}{|c|}{ Process } & \multirow{2}{*}{ Productive State } & \multirow{2}{*}{ Monitoring } \\
\hline & & & Indication & Symbol & & \\
\hline $\begin{array}{l}\text { Free-hand } \\
\text { Performing }\end{array}$ & FHP & work element & Operation & $\mathrm{O}$ & $\begin{array}{l}\text { Productive or } \\
\text { Direct work }\end{array}$ & BM \\
\hline Auxiliary tools & AUT & work element & Inspection & $\square$ & $\begin{array}{c}\text { Contributory } \\
\text { orSupport work }\end{array}$ & $\mathrm{BM}$ \\
\hline Manual tools & MNT & work element & Operation & $\mathrm{O}$ & $\begin{array}{l}\text { Productive or } \\
\text { Direct work }\end{array}$ & $\mathrm{BM}$ \\
\hline $\begin{array}{l}\text { Electric/electronic } \\
\text { tools }\end{array}$ & EET & work element & Operation & $\mathrm{O}$ & $\begin{array}{l}\text { Productive or } \\
\text { Direct work }\end{array}$ & $\mathrm{BM}+\mathrm{So}$ \\
\hline Machines operation & MOP & work element & Operation & $\mathrm{O}$ & $\begin{array}{l}\text { Productive or } \\
\text { Direct work }\end{array}$ & $\mathrm{BM}+\mathrm{Loc}+\mathrm{So}$ \\
\hline Robotic automation & RBA & autonomous & Operation & $\mathrm{O}$ & $\begin{array}{l}\text { Autonomous } \\
\text { Production }\end{array}$ & $\mathrm{BM}+\mathrm{Loc}+\mathrm{So}$ \\
\hline $\begin{array}{l}\text { Do not operate } \\
\text { value }\end{array}$ & IDL & $\begin{array}{l}\text { basic motion } \\
\text { element }\end{array}$ & Delay & $\mathrm{D}$ & $\begin{array}{l}\text { Nonproduction } \\
\text { work }\end{array}$ & $\mathrm{BM}+\mathrm{Loc}$ \\
\hline Walking & WLK & $\begin{array}{l}\text { basic motion } \\
\text { element }\end{array}$ & Delay & $\mathrm{D}$ & $\begin{array}{l}\text { Nonproduction } \\
\text { work }\end{array}$ & $\mathrm{BM}+\mathrm{Loc}$ \\
\hline Carrying & CAR & $\begin{array}{l}\text { basic motion } \\
\text { element }\end{array}$ & $\begin{array}{l}\text { Transportation/ } \\
\text { Storage }\end{array}$ & $\Delta \rightarrow$ & $\begin{array}{c}\text { Contributory } \\
\text { orSupport work }\end{array}$ & $\mathrm{BM}+\mathrm{Loc}$ \\
\hline
\end{tabular}

BM-body motion; Loc—location ( $\mathrm{x} ; \mathrm{y} ; \mathrm{z})$; So—sound detector.

\subsection{Flowchart to Increase Efficiency and Mechanization Level Measurement}

Figure 5 presents a flowchart of processes or the Worker 4.0 motion productivity to boost productivity framework. Based on the following assumptions and the designed flow, Table 5 presents the first analysis indications on how to boost efficiency and mechanization levels.

Assumption 1. All construction activities have a mix of operations performed only with the hands and others with the aid of tools (either manual or auxiliary or electrical) or machines or equipment;

Assumption 2. The handwork component (with one or both hands) is intrinsic/inherent to construction activities;

Assumption 3. Operating times should be maximized;

Assumption 4. Automated and Mechanical performances are higher than manual performance;

Assumption 5. Processes performed with tools have higher performance than the manual ones (not using tools);

Assumption 6. To achieve improved productivity, the tasks processes should be mechanized or automated;

Assumption 7. Inspections and verifications performed by the workers themselves should be reduced;

Assumption 8. Easily assembled templates and elements that require no measurement are prone to accelerate processes. 


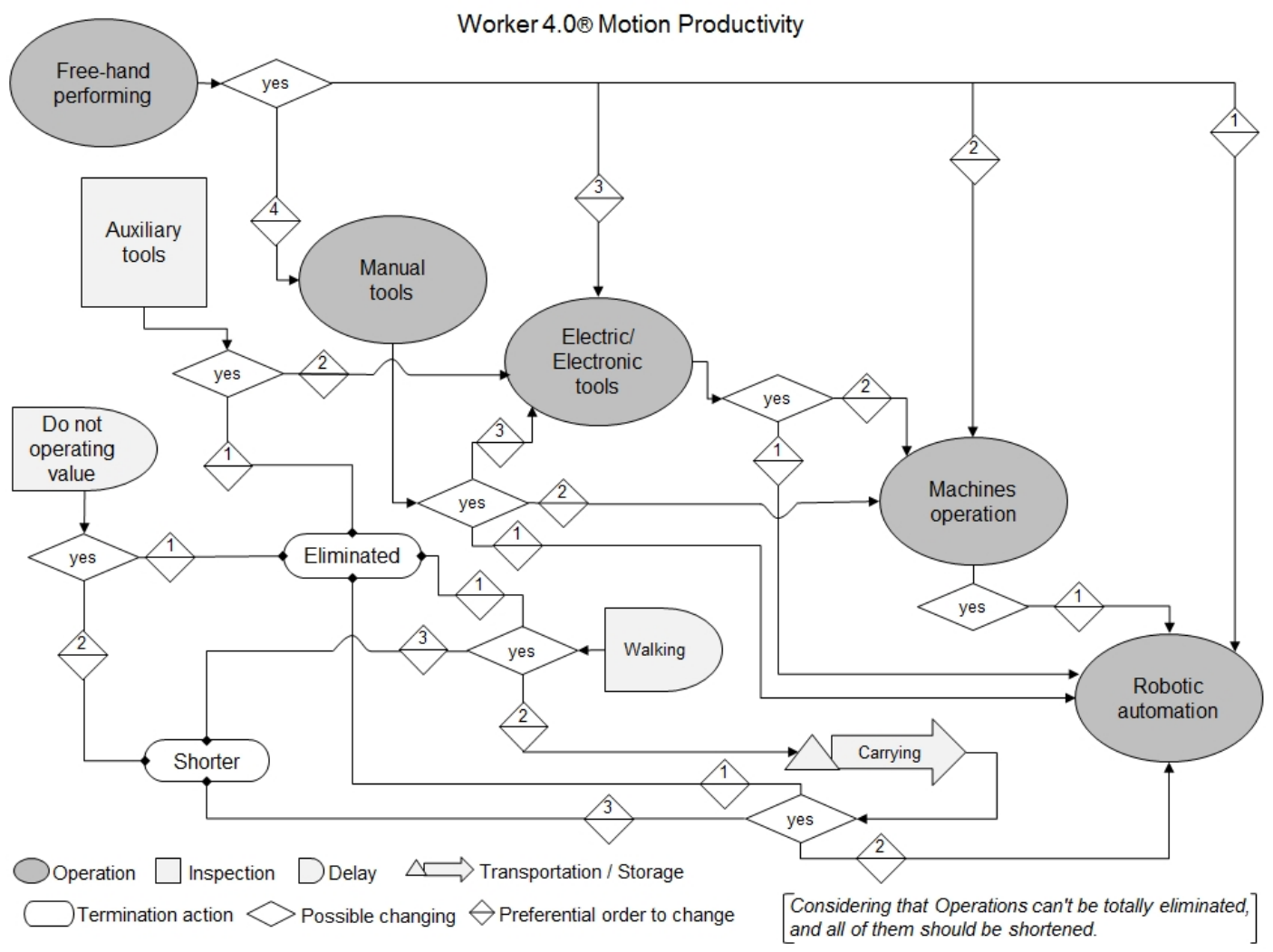

Figure 5. Worker 4.0: Flowchart to increase efficiency.

Table 5. Worker 4.0: motion productivity (W4MP)-improving process.

\begin{tabular}{|c|c|}
\hline $\begin{array}{l}\text { Worker 4.0 Motion } \\
\text { Productivity }\end{array}$ & $\begin{array}{c}\text { First Analysis Indications on How to Boost Efficiency and } \\
\text { Mechanization Levels }\end{array}$ \\
\hline Free-hand performing & $\begin{array}{c}\text { Does the activity justify the use of any tool, mechanized or automated } \\
\text { robotic equipment? }\end{array}$ \\
\hline Auxiliary tools & Can it be eliminated? Can it be used as an electric/electronic tool? \\
\hline Manual tools & $\begin{array}{l}\text { Does the activity justify the use of an electric/electronic tool or mechanized or } \\
\text { automated robotic equipment? }\end{array}$ \\
\hline Electric/electronic tools & Does the activity justify mechanized or automated robotic equipment? \\
\hline Machines operation & Does the activity justify automated robotic equipment? \\
\hline Robotic automation & $\begin{array}{l}\text { If that robotic solution demand for workforce auxiliary work, can it be avoided or } \\
\text { shortened? }\end{array}$ \\
\hline Do not operate value & Can it be avoided or shortened? \\
\hline Walking & Can it be avoided or shortened? Can the worker carry something? \\
\hline Carrying & Can it be avoided or shortened? Does the activity justify automated equipment? \\
\hline
\end{tabular}

According to Hwang et al. [103], there is no academic research on the assessment of mechanization in building construction projects. Hwang et al. [103] proposed a mechanization index assessment tool for projects based on a detailed analysis of the tools and measuring the level value regarding a qualitative survey.

Based on the Worker 4.0 motion productivity (W4MP), it is possible to quantitative measure the mechanization of the tasks conducted by the craft workforce. Equation (1) presents the W4MP Mechanization index. The concept measures the proportion of the three mechanized processes (EET—electric/electronic tools; MOP—machines operation; RBA—robotic automation) 
upon the operation processes, without considering the other processes as inspection, delay and transportation/storage.

$$
(\mathrm{M} 4 \mathrm{MP}) \text { Mechanization index }=\frac{\mathrm{EET}+\mathrm{MOP}+\mathrm{RBA}}{\sum \text { Operation Processes }},
$$

where:

$$
\begin{aligned}
& \text { EET = electric/electronic tools; } \\
& \text { MOP = machines operation; } \\
& \text { RBA = robotic automation; } \\
& \text { Operation process = (FHP + MNT + EET + MOP + RBA }) ; \\
& \text { FHP = free-hand performing; } \\
& \text { MNT = manual tools. }
\end{aligned}
$$

The analysis of these results based on the status quo of building construction tasks a classification scale is proposed, as follows:

- $\quad$ Low- $0 \%$ to $20 \%$;

- Moderate- $21 \%$ to $40 \%$;

- High- $41 \%$ to $60 \%$;

- Very high—above $61 \%$.

It is based on the qualitative analysis of the responses regarding the efficiency of the processes and the quantitative values of each process and the mechanization index that the W4MP method will allow ways to improve productivity in the on-site construction projects.

\subsection{Tasks Process Modelling Chart}

The monitoring of both hands can allow the formation of a left-hand/right-hand chart (very applied in assembly process modelling $[3,4,109])$. Where, each hand instant motion is classified as a known process (e.g., therblig) and is plotted into two timeline columns $[3,4,109]$. The concept of this chart is evaluating the workers' operation to eliminate one-handed operation [109]. It is known that it is impossible to use both hands for the entire working time [109]. However, it is observed that the manufacturing industry has improved its operations using this method for workstations evaluation $[3,4,109]$.

The Worker 4.0 modelling chart was designed based on that two-handed chart (see Figure 6). This chart consolidates all the concepts above presented. At the top left (first and second columns), it presents the information about the task and the worker (e.g., work package, output quantity, worker profession, day and time). A chart evidences that the proportionality of the processes labelled could be seen at the middle top. Finally, at the top right, a summary timing based on the Worker 4.0 motion productivity processes are presented where the cycle time and the performance efficiency can be determinate. In the chart sequence, appear twelve informative columns, where at the center can be seen one column with the information of geo-position $(x ; y ; z)$ or a BIM space/tag identification, side by side it presents two columns with graduation (time) and colors (the type of process). Next, this centered column from left (four columns) and right (four columns) presents the respective pieces of information about workers hands and legs. Where on leg and hand information it may show a detailed classification of the activity (e.g., holding, sawing, walking). Also, for each labelled hand/leg the detailed information has time duration measured and a Worker 4.0 motion productivity (W4MP) classification describing the activity. Finally, a column in the right presents the workers estimated amount of calories expended. If it is not an already known activity, it will appear as (?), when the analyst identifies that task (e.g., hammering) the processing system method (e.g., machine learning) understands it and records for labeling. Forward, this gap is filled as labeled (e.g., hammering). The system in the next similar activity one "registers" the pattern of the new action identified. 


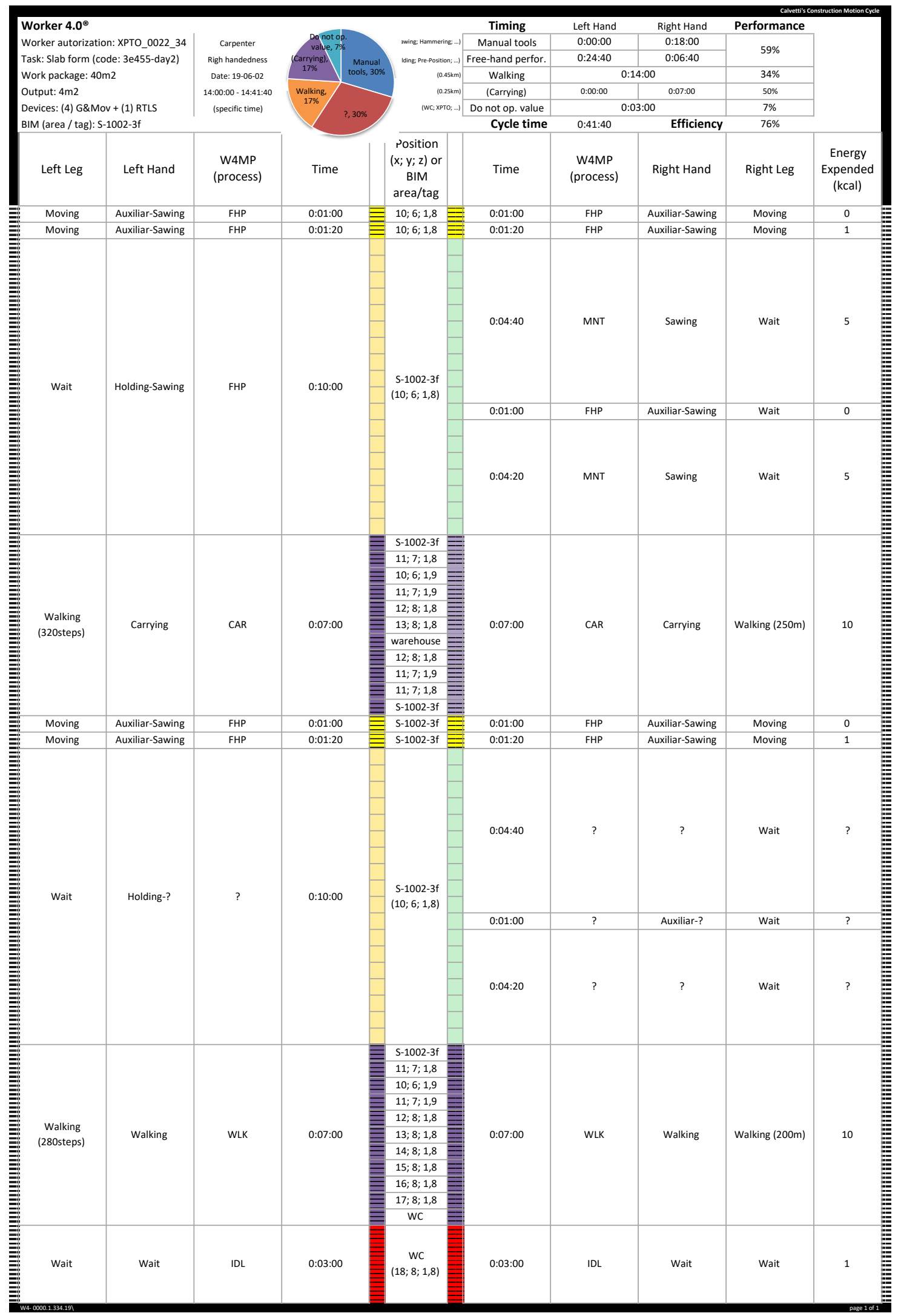

Figure 6. Worker 4.0: Two-handed, two-legged modeling chart. 
The Worker 4.0 modeling chart enables the modeling of production processes for a detailed analysis of productivity. It is possible to evaluate in time (hours, minutes and even seconds) the workers' motions captured by the sensing wearables technology (in the case hands and legs). Still, it is possible to increase the analysis and the algorithms based on geolocation and also tools' noise. The processing of data through artificial intelligence will allow the automation of the activities labeling. In this way, a future system can be organically supplied, only giving rise to small calibrations and adjustments. This chart can provide a streamlined view on productivity that can be used for multiple purposes such as training, by comparing an optimal performance with each worker results.

\section{Discussion}

Worker 4.0 is a concept that materializes the main principles and behavior of workers in a Construction 4.0 scenario. The craft-workforce-centered concept is illustrated in Figure 7. It is precisely because the Worker 4.0 motion productivity is designed for the control and continuous improvement of processes that the four-step management method PDCA is adequate to conduct that. First, the innovation project based on the methodologies of Worker 4.0 motion productivity that are craft-workforce-centered must be planned. The next step is to complete data collection and processing. Hence, the performance checks of the processes to assess the level of mechanization. The final step is to act on on-site productivity, implementing actions to control and set up continuous improvement procedures.

However, the high hierarchy of the company must authorize and sponsor the innovation project, defining the premises and the requirements for the development of electronic control. Hence, a program and specifications for the evaluation of productivity should be conducted based on project management premises. A process should define the plan to implement the electronic measurement, as well as, the business rules and software systems for data analysis to develop. After this, it is necessary to implement the infrastructure on the construction site-as well as install the sensors. Up to this point that can identify a cycle of planning, specifications and actions that enable data collection and analysis. Workers who will undergo monitoring should receive information and training regarding devices. As well as, in light with the legal and ethical rules, they should consent the collection of data regarding their performance during the execution of the daily tasks. With the system in operational hardware and software, the on-site data collection begins, and the analysis of this information is a startup. This cycle of productivity control with the collection and analysis of situational data should trigger in an improvement process, with the implementation of a productivity action plan. The first cycle of program and implementation should occur periodically, based on the strategic management of the business. On the other hand, the cycle of control and improvement must occur according to the cost-benefit analysis and can be either continuous or periodic. Such an analysis should be based on the quantitative and qualitative values determined in the measurement and the consequent opportunity to improve the productive indices.

Stakeholders from different knowledge will be interacting with this type of innovative method, for example as:

- Directors (authorization and sponsoring);

- Manager (project management);

- Field engineers (conduct the implementation and the assessment);

- Human resources specialists (regulation and support);

- Planners and quality engineers (time schedule and improvement plans);

- Craft workers (GDPR consent and work under monitoring).

Mutual benefits for both employees and employers should be a target as crucial success factors of EPM. A well-trained craft workforce and the awareness of their own performance will potentially increase projects profits into a cycle of optimization and maximization of jobs in the CI. 


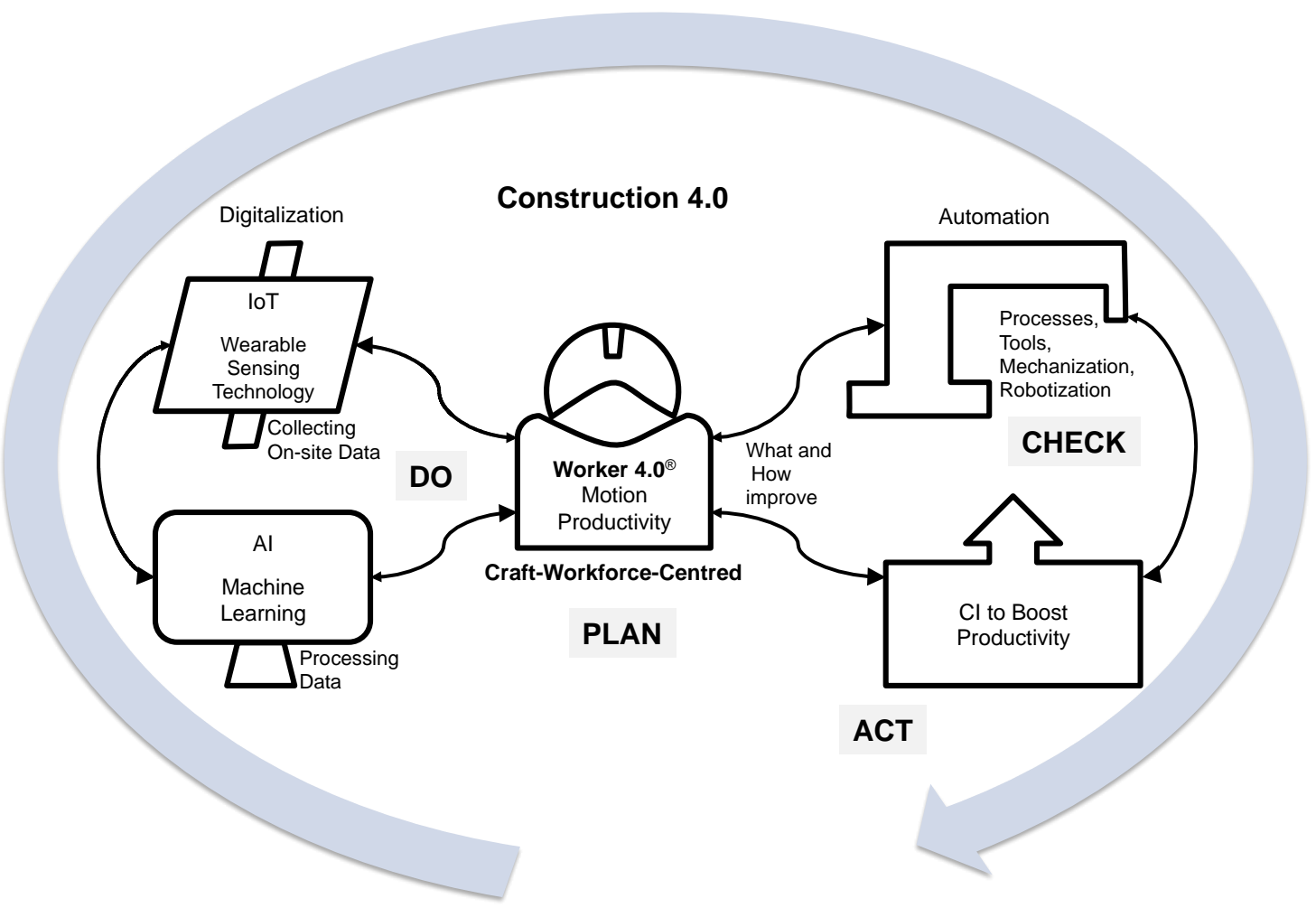

Figure 7. Worker 4.0: Craft-workforce-centered.

Within a vast universe of tasks developed in engineering projects, a gain in process improvement allows for better performance in terms of time and cost. By improving the worker efficiency and team productivity, improvements are obtained (e.g., outputs as $\mathrm{m}^{2}$ and $\mathrm{m}^{3}$ ) in each task. As stated before, task performance in the construction industry is directly linked to the physical effort of workers (where labor-hours are usually used as input) and it drives the tasks time leading. Often, by reducing task labor-hours, the time to complete a task is reduced. Finally, a significant amount of task costs is linked to craft workforce costs. As exemplified below, in the price formation [111] of three typical CI tasks (masonry, concrete and painting) the craft workforce accounts for $47.51 \%$ to $67.13 \%$ of the total cost. In fact, an improvement in the tasks processes leads to significant cost reductions:

- Triple perforated ceramic brick, to be coated, $30 \mathrm{~cm} \times 20 \mathrm{~cm} \times 15 \mathrm{~cm}$, for use in protected masonry (piece P), density $650 \mathrm{~kg} / \mathrm{m}^{3}$, according to NP EN 771-1. Yield of 0.733 labor-hours per $\mathrm{m}^{2}$. Total cost of 20.08 Euros per $\mathrm{m}^{2}$, where 13.48 Euros $(67.13 \%)$ are related to craft workforce [111];

- High, straight, reinforced concrete beam, $40 \mathrm{~cm} \times 60 \mathrm{~cm}$, made with C25/30 concrete (XC1 (P); D12; S3; Cl 0.4) prepared on-site and concreting with manual means and A400 NR steel, with an amount of approximately $150 \mathrm{~kg} / \mathrm{m}^{3}$; assembly and disassembly of the formwork system, with finish to coat, on floors up to three meters free height. Yield of 10.43 labor-hours per $\mathrm{m}^{3}$. Total cost of 419.51 Euros per $\mathrm{m}^{3}$, where 199.29 Euros (47.51\%) are related to craft workforce [111];

- Manual application of two coats of white plastic paint, matte finish, smooth texture, the first coat diluted with 15 to $20 \%$ water and the next diluted with 5 to $10 \%$ water or undiluted, (yield: $0.1 \mathrm{~L} / \mathrm{m}^{2}$ each coat); prior application of a coat of acrylic primer regulating the absorption, on the external mortar wall. Yield of 0.25 labor-hours per $\mathrm{m}^{2}$. Total cost of 7.31 Euros per $\mathrm{m}^{2}$, where 4.66 Euros $(63.75 \%)$ are related to craft workforce [111].

The work developed led to the systematization of the craft workforce productivity process for the construction industry. The proposed method has direct implications with the characteristics of the works to be developed, the site conditions, as well as the type of organization and willingness of the workers. These assume a crucial role in terms of future headings of the research and, at the same 
time, constitute an opportunity to raise the bar of the industry image regarding the craft workforce. The proposal ranged a multilevel approach and looked for all aspects of innovation framed within the trends of Construction 4.0.

One of the biggest challenges of implementing workforce electronic performance monitoring is the compliance with the GDPR [112]. The awareness and consent of each worker is vital to create safe environments that are ethically delegated by pre-established collective-agreements rules and GDPR compliant [112].

The added value of this work for the CI can be improved through the integration of measurement methodologies and data collection devices. These-in addition to the improved support for the selection of the appropriate level of performance productivity assessment-may allow, among others, the best integration with the human productivity factors, as well as guidelines and awareness for the continuous improvement of workers and teams skills. By modeling the tasks, it will be possible the productivity assessment, both for workers as individuals and teams and forward, based on that, an overall on-site productivity vision, achieving a project best performance.

Short-term future research directions (led by the authors and other research groups) are focused on conducting a set of laboratory/on-site experiments based on electronic monitoring with a broader workforce sample - to test systems and the performance of algorithms in a near-real practical application. These cases studies will also allow fulfilling the proposed Worker 4.0 motion methods searching for improvement in order to evolve to an operational system. Regarding long-term future research, the authors hope to apply the methodology to construction companies to evaluate the methodology effectiveness in real-world scenarios.

Craft-workforce-centered construction performance transformation is possible by inspiring people on-site to embrace 4.0 innovations. The challenge of increasing productivity will be achieved by making the tasks processes easier, with less effort, more autonomous and implementing technology to measure performance. In the current context, health and safety issues gain even more relevance and the topic may work as an enabler towards the implementation of several innovations.

\section{Patents}

Worker 4.0 is a registered brand (Calvetti, Diego. 2019. WORKER 4.0. National brand. Portugal, number 616437, filed January 07.).

Author Contributions: Conceptualization, D.C. and P.M.; Methodology, D.C., P.M. and M.C.G.; Validation M.C.G., and H.S.; Investigation, D.C.; Writing-Original Draft Preparation, D.C. and P.M.; Writing-Review \& Editing, D.C. and P.M.; Supervision, M.C.G.; Project Administration, H.S.; Funding Acquisition, H.S. All authors have read and agreed to the published version of the manuscript.

Funding: This work was financially supported by: Base Funding-UIDB/04708/2020 of the CONSTRUCT—Instituto de I\&D em Estruturas e Construções-funded by national funds through the FCT/MCTES (PIDDAC).

Conflicts of Interest: The authors declare no conflict of interest.

\section{References}

1. Desruelle, P.; Baldini, G.; Barboni, M.; Bono, F.; Delipetrev, B.; Duch Brown, N.; Fernandez Macias, E.; Gkoumas, K.; Joossens, E.; Kalpaka, A.; et al. Digital Transformation in Transport, Construction, Energy, Government and Public Administration; EUR 29782 EN; Publications Office of the European Union: Luxembourg, 2019. [CrossRef]

2. Yang, J.; Park, M.W.; Vela, P.A.; Golparvar-Fard, M. Construction Performance Monitoring via Still Images, Time-Lapse Photos, and Video Streams: Now, Tomorrow, and the Future. Adv. Eng. Inform. 2015, 29, $211-224$. [CrossRef]

3. Freivalds, A. Niebel's Methods, Standards, and Work Design; Mcgraw-Hill Higher Education: Boston, MA, USA, 2009; Volume 700.

4. Groover, M.P. Work Systems and the Methods, Measurement, and Management of Work; Pearson Prentice Hall: Upper Saddle River, NJ, USA, 2007. 
5. Sink, D.S. Productivity Management: Planning, Measurement and Evaluation, Control, and Improvement; John Wiley \& Sons: New York, NY, USA, 1985.

6. Cheng, T.; Teizer, J.; Migliaccio, G.C.; Gatti, U.C. Automated Task-Level Activity Analysis through Fusion of Real Time Location Sensors and Worker's Thoracic Posture Data. Autom. Constr. 2013, 29, 24-39. [CrossRef]

7. Gong, J.; Caldas, C.H. An Object Recognition, Tracking, and Contextual Reasoning-Based Video Interpretation Method for Rapid Productivity Analysis of Construction Operations. Autom. Constr. 2011, 20, 1211-1226. [CrossRef]

8. Khosrowpour, A.; Niebles, J.C.; Golparvar-Fard, M. Vision-Based Workface Assessment Using Depth Images for Activity Analysis of Interior Construction Operations. Autom. Constr. 2014, 48, 74-87. [CrossRef]

9. Mani, N.; Kisi, K.P.; Rojas, E.M.; Foster, E.T. Estimating Construction Labor Productivity Frontier: Pilot Study. J. Constr. Eng. Manag. 2017, 143. [CrossRef]

10. Aryal, A.; Ghahramani, A.; Becerik-Gerber, B. Monitoring Fatigue in Construction Workers Using Physiological Measurements. Autom. Constr. 2017, 82, 154-165. [CrossRef]

11. Guo, H.; Yu, Y.; Xiang, T.; Li, H.; Zhang, D. The Availability of Wearable-Device-Based Physical Data for the Measurement of Construction Workers' Psychological Status on Site: From the Perspective of Safety Management. Autom. Constr. 2017, 82, 207-217. [CrossRef]

12. Leaps, S.R.O. Social Distancing Monitor|LEAPS. Available online: https://www.leapslabs.com/sdm (accessed on 30 July 2020).

13. RIBA (Ed.) The RIBA Plan of Work 2020; RIBA Architecture: London, UK, 2020.

14. Mêda, P.; Hjelseth, E.; Sousa, H. Construction Information Framework-The Role of Classification Systems. In eWork and eBusiness in Architecture, Engineering and Construction, Proceedings of the 11th European Conference on Product and Process Modelling (ECPPM 2016), Limassol, Cyprus, 7-9 September 2016; CRC Press: London, UK, 2016; ISBN 978-1-38-03280-4.

15. Calvetti, D.; Gonçalves, M.C.; Magalhães, P.N.M.; de Sousa, H.J.C. Sensing Technologies Embedding Construction Workers Outcomes/Key Performance Indicators. In Proceedings of the 36th CIB W78 2019 Conference: Advances in ICT in Design, Construction and Management in Architecture, Engineering, Construction and Operations (AECO), Newcastle, UK, 18-20 September 2019; Kumar, B., Rahimian, F., Greenwood, D., Hartmann, T., Eds.; CIB W78: Newcastle, UK, 2019; pp. 890-900, ISBN (Print) 9781861354877, ISBN (eBook) 9781861354860.

16. ISO 12006-2. ISO 12006-2:2015 Building Construction-Organization of Information about Construction Works-Part 2: Framework for Classification; International Organization for Standardization: Geneva, Switzerland, 2015.

17. Liou, F.; Borcherding John, D. Work Sampling Can Predict Unit Rate Productivity. J. Constr. Eng. Manag. 1986, 112, 90-103. [CrossRef]

18. Akhavian, R.; Behzadan, A. Wearable Sensor-Based Activity Recognition for Data-Driven Simulation of Construction Workers' Activities. In Proceedings of the Proceedings-Winter Simulation Conference, Huntington Beach, CA, USA, 6-9 December 2016; Volume 2016, pp. 3333-3344. [CrossRef]

19. Akhavian, R.; Brito, L.; Behzadan, A. Integrated Mobile Sensor-Based Activity Recognition of Construction Equipment and Human Crews. In Proceedings of the Conference on Autonomous and Robotic Construction of Infrastructure, Ames, IA, USA, 2-3 June 2015; pp. 1-20.

20. Akhavian, R.; Behzadan, A.H. Smartphone-Based Construction Workers' Activity Recognition and Classification. Autom. Constr. 2016, 71, 198-209. [CrossRef]

21. Akhavian, R.; Behzadan, A.H. Coupling Human Activity Recognition and Wearable Sensors for Data-Driven Construction Simulation. J. Inf. Technol. Constr. 2018, 23, 1-15.

22. Akhavian, R.; Behzadan, A.H. Productivity Analysis of Construction Worker Activities Using Smartphone Sensors. In Proceedings of the 16th International Conference on Computing in Civil and Building Engineering (ICCCBE), Osaka, Japan, 6-8 July 2016; pp. 1067-1074.

23. Zhang, M.; Chen, S.; Zhao, X.; Yang, Z. Research on Construction Workers' Activity Recognition Based on Smartphone. Sensors 2018, 18, 2667. [CrossRef]

24. Zheng, X.; Wang, M.; Ordieres-Meré, J. Comparison of Data Preprocessing Approaches for Applying Deep Learning to Human Activity Recognition in the Context of Industry 4.0. Sensors 2018, 18, 2146. [CrossRef]

25. Tao, W.; Lai, Z.H.; Leu, M.C.; Yin, Z. Worker Activity Recognition in Smart Manufacturing Using IMU and SEMG Signals with Convolutional Neural Networks. Procedia Manuf. 2018, 26, 1159-1166. [CrossRef] 
26. Ordóñez, F.J.; Roggen, D. Deep Convolutional and LSTM Recurrent Neural Networks for Multimodal Wearable Activity Recognition. Sensors 2016, 16, 115. [CrossRef]

27. Juhyeong, R.; Seo, J.; Liu, M.; Lee, S.; Haas, C.T. Action Recognition Using a Wristband-Type Activity Tracker: Case Study of Masonry Work. In Construction Research Congress 2016; ASCE: San Juan, Puerto Rico, 2016; pp. 790-799.

28. Ryu, J.; Seo, J.; Jebelli, H.; Lee, S. Automated Action Recognition Using an Accelerometer-Embedded Wristband-Type Activity Tracker. J. Constr. Eng. Manag. 2019, 145, 04018114. [CrossRef]

29. Joshua, L.; Varghese, K. Classification of Bricklaying Activities in Work Sampling Categories Using Accelerometers. In Construction Research Congress 2012: Construction Challenges in a Flat World; ASCE: West Lafayette, Indiana, 2012; pp. 919-928. [CrossRef]

30. Joshua, L.; Varghese, K. Automated Recognition of Construction Labour Activity Using Accelerometers in Field Situations. Int. J. Product. Perform. Manag. 2014, 63, 841-862. [CrossRef]

31. Joshua, L.; Varghese, K. Accelerometer-Based Activity Recognition in Construction. J. Comput. Civ. Eng. 2011, 25, 370-379. [CrossRef]

32. Qi, B.; Razkenari, M.; Li, J.; Costin, A.; Kibert, C.; Qian, S. Investigating U.S. Industry Practitioners' Perspectives towards the Adoption of Emerging Technologies in Industrialized Construction. Buildings 2020, 10, 85. [CrossRef]

33. Moradi, S.; Kähkönen, K.; Aaltonen, K. Project Managers' Competencies in Collaborative Construction Projects. Buildings 2020, 10, 50. [CrossRef]

34. Cheng, T.; Mantripragada, U.; Teizer, J.; Vela, P.A. Automated Trajectory and Path Planning Analysis Based on Ultra Wideband Data. J. Comput. Civ. Eng. 2012, 26, 151-160. [CrossRef]

35. Kumari, P.; Mathew, L.; Syal, P. Increasing Trend of Wearables and Multimodal Interface for Human Activity Monitoring: A Review. Biosens. Bioelectron. 2017, 90, 298-307. [CrossRef]

36. Khoury, H.; Chdid, D.; Oueis, R.; Elhajj, I.; Asmar, D. Infrastructureless Approach for Ubiquitous User Location Tracking in Construction Environments. Autom. Constr. 2015, 56, 47-66. [CrossRef]

37. Nguyen, L.V.; La, H.M.; Sanchez, J.; Vu, T. A Smart Shoe for Building a Real-Time 3D Map. Autom. Constr. 2016, 71, 2-12. [CrossRef]

38. Yan, X.; Li, H.; Li, A.R.; Zhang, H. Wearable IMU-Based Real-Time Motion Warning System for Construction Workers' Musculoskeletal Disorders Prevention. Autom. Constr. 2017, 74, 2-11. [CrossRef]

39. Dupont, Q.F.M.; Chua, D.K.H.; Tashrif, A.; Abbott, E.L.S. Potential Applications of UAV along the Construction's Value Chain. Procedia Eng. 2017, 182, 165-173. [CrossRef]

40. Han, K.K.; Golparvar-Fard, M. Potential of Big Visual Data and Building Information Modeling for Construction Performance Analytics: An Exploratory Study. Autom. Constr. 2017, 73, 184-198. [CrossRef]

41. Han, S.; Lee, S. A Vision-Based Motion Capture and Recognition Framework for Behavior-Based Safety Management. Autom. Constr. 2013, 35, 131-141. [CrossRef]

42. Kurien, M.; Kim, M.-K.; Kopsida, M.; Brilakis, I. Real-Time Simulation of Construction Workers Using Combined Human Body and Hand Tracking for Robotic Construction Worker System. Autom. Constr. 2018, 86, 125-137. [CrossRef]

43. Yu, Y.; Guo, H.; Ding, Q.; Li, H.; Skitmore, M. An Experimental Study of Real-Time Identification of Construction Workers' Unsafe Behaviors. Autom. Constr. 2017, 82, 193-206. [CrossRef]

44. Teizer, J.; Caldas, C.H.; Haas, C.T. Real-Time Three-Dimensional Occupancy Grid Modeling for the Detection and Tracking of Construction Resources. J. Constr. Eng. Manag. 2007, 133, 880-888. [CrossRef]

45. Han, K.K.; Cline, D.; Golparvar-Fard, M. Formalized Knowledge of Construction Sequencing for Visual Monitoring of Work-in-Progress via Incomplete Point Clouds and Low-LoD 4D BIMs. Adv. Eng. Inform. 2015, 29, 889-901. [CrossRef]

46. Han, K.K.; Golparvar-Fard, M. Appearance-Based Material Classification for Monitoring of Operation-Level Construction Progress Using 4D BIM and Site Photologs. Autom. Constr. 2015, 53, 44-57. [CrossRef]

47. Rebolj, D.; Pučko, Z.; Babič, N.Č.; Bizjak, M.; Mongus, D. Point Cloud Quality Requirements for Scan-vs-BIM Based Automated Construction Progress Monitoring. Autom. Constr. 2017, 84, 323-334. [CrossRef]

48. Costin, A.; Pradhananga, N.; Teizer, J. Leveraging Passive RFID Technology for Construction Resource Field Mobility and Status Monitoring in a High-Rise Renovation Project. Autom. Constr. 2012, 24, 1-15. [CrossRef] 
49. Kelm, A.; Laußat, L.; Meins-Becker, A.; Platz, D.; Khazaee, M.J.; Costin, A.M.; Helmus, M.; Teizer, J. Mobile Passive Radio Frequency Identification (RFID) Portal for Automated and Rapid Control of Personal Protective Equipment (PPE) on Construction Sites. Autom. Constr. 2013, 36, 38-52. [CrossRef]

50. Teizer, J.; Allread, B.S.; Fullerton, C.E.; Hinze, J. Autonomous Pro-Active Real-Time Construction Worker and Equipment Operator Proximity Safety Alert System. Autom. Constr. 2010, 19, 630-640. [CrossRef]

51. Woo, S.; Jeong, S.; Mok, E.; Xia, L.; Choi, C.; Pyeon, M.; Heo, J. Application of WiFi-Based Indoor Positioning System for Labor Tracking at Construction Sites: A Case Study in Guangzhou MTR. Autom. Constr. 2011, 20, 3-13. [CrossRef]

52. Zhou, C.; Ding, L.Y. Safety Barrier Warning System for Underground Construction Sites Using Internet-of-Things Technologies. Autom. Constr. 2017, 83, 372-389. [CrossRef]

53. Cheng, T.; Teizer, J. Real-Time Resource Location Data Collection and Visualization Technology for Construction Safety and Activity Monitoring Applications. Autom. Constr. 2013, 34, 3-15. [CrossRef]

54. Cheng, T.; Migliaccio, G.C.; Teizer, J.; Gatti, U.C. Data Fusion of Real-Time Location Sensing and Physiological Status Monitoring for Ergonomics Analysis of Construction Workers. J. Comput. Civ. Eng. 2013, 27, 320-335. [CrossRef]

55. Cheng, T.; Venugopal, M.; Teizer, J.; Vela, P.A. Performance Evaluation of Ultra Wideband Technology for Construction Resource Location Tracking in Harsh Environments. Autom. Constr. 2011, 20, 1173-1184. [CrossRef]

56. Choi, B.; Hwang, S.; Lee, S.H. What Drives Construction Workers' Acceptance of Wearable Technologies in the Workplace? Indoor Localization and Wearable Health Devices for Occupational Safety and Health. Autom. Constr. 2017, 84, 31-41. [CrossRef]

57. Teizer, J.; Cheng, T. Proximity Hazard Indicator for Workers-on-Foot near Miss Interactions with Construction Equipment and Geo-Referenced Hazard Areas. Autom. Constr. 2015, 60, 58-73. [CrossRef]

58. Teizer, J.; Cheng, T.; Fang, Y.H. Location Tracking and Data Visualization Technology to Advance Construction Ironworkers' Education and Training in Safety and Productivity. Autom. Constr. 2013, 35, 53-68. [CrossRef]

59. Calvetti, D. Evaluation of the Electronic Methodology for Monitoring the Performance of Welders in Pipe Manufacturing; Federal Fluminense University: Niterói, Brazil, 2016.

60. Jiang, H.; Lin, P.; Qiang, M.; Fan, Q. A Labor Consumption Measurement System Based on Real-Time Tracking Technology for Dam Construction Site. Autom. Constr. 2015, 52, 1-15. [CrossRef]

61. Navon, R. Automated Project Performance Control of Construction Projects. Autom. Constr. 2005, 14, 467-476. [CrossRef]

62. Navon, R.; Goldschmidt, E. Monitoring Labor Inputs- Automated-Data-Collection Model and Enabling Technologies. Autom. Constr. 2002, 12, 185-199. [CrossRef]

63. Navon, R.; Goldschmidt, E. Can Labor Inputs Be Measured and Controlled Automatically? J. Constr. Eng. Manag. 2003, 129, 437-445. [CrossRef]

64. Valero, E.; Sivanathan, A.; Bosché, F.; Abdel-Wahab, M. Analysis of Construction Trade Worker Body Motions Using a Wearable and Wireless Motion Sensor Network. Autom. Constr. 2017, 83, 48-55. [CrossRef]

65. Chen, J.; Qiu, J.; Ahn, C. Construction Worker's Awkward Posture Recognition through Supervised Motion Tensor Decomposition. Autom. Constr. 2017, 77, 67-81. [CrossRef]

66. Tserng, H.P.; Dzeng, R.J.; Lin, Y.C.; Lin, S.T. Mobile Construction Supply Chain Management Using PDA and Bar Codes. Comput. Civ. Infrastruct. Eng. 2005, 20, 242-264. [CrossRef]

67. Shehab, T.; Moselhi, O.; Nasr, E. Barcode-Assisted System for Document Management of Construction Projects. Int. J. Constr. Educ. Res. 2009, 5, 45-60. [CrossRef]

68. Chen, J.; Song, X.; Lin, Z. Revealing the "Invisible Gorilla" in Construction: Estimating Construction Safety through Mental Workload Assessment. Autom. Constr. 2016, 63, 173-183. [CrossRef]

69. Hwang, S.; Seo, J.; Jebelli, H.; Lee, S. Feasibility Analysis of Heart Rate Monitoring of Construction Workers Using a Photoplethysmography (PPG) Sensor Embedded in a Wristband-Type Activity Tracker. Autom. Constr. 2016, 71, 372-381. [CrossRef]

70. Hwang, S.; Lee, S.H. Wristband-Type Wearable Health Devices to Measure Construction Workers' Physical Demands. Autom. Constr. 2017, 83, 330-340. [CrossRef]

71. Lee, W.; Lin, K.Y.; Seto, E.; Migliaccio, G.C. Wearable Sensors for Monitoring On-Duty and Off-Duty Worker Physiological Status and Activities in Construction. Autom. Constr. 2017, 83, 341-353. [CrossRef] 
72. Peterson, B. There's A New Version of Google Glass, and it's Been Secretly Used by Hundreds of Factory Workers for the Last Two Years. Available online: http://www.businessinsider.com/theres-a-new-version-ofgoogle-glass-and-its-been-secretly-used-by-hundreds-of-factory-workers-for-the-last-two-years-2017-7 (accessed on 10 November 2019).

73. Microsoft. Microsoft HoloLens. Available online: https://www.microsoft.com/en-us/hololens (accessed on 5 October 2018).

74. Athos. Available online: https://www.liveathos.com (accessed on 5 October 2018).

75. Movit. Motiv Ring. Available online: https://mymotiv.com/motiv-ring (accessed on 5 October 2018).

76. Nuada. NUADA. Available online: http://nuada.pt (accessed on 5 October 2018).

77. Memarzadeh, M.; Golparvar-Fard, M.; Niebles, J.C. Automated 2D Detection of Construction Equipment and Workers from Site Video Streams Using Histograms of Oriented Gradients and Colors. Autom. Constr. 2013, 32, 24-37. [CrossRef]

78. Park, M.-W.; Brilakis, I. Construction Worker Detection in Video Frames for Initializing Vision Trackers. Autom. Constr. 2012, 28, 15-25. [CrossRef]

79. Park, M.-W.; Brilakis, I. Continuous Localization of Construction Workers via Integration of Detection and Tracking. Autom. Constr. 2016, 72, 129-142. [CrossRef]

80. Yang, J.; Arif, O.; Vela, P.A.; Teizer, J.; Shi, Z. Tracking Multiple Workers on Construction Sites Using Video Cameras. Adv. Eng. Inform. 2010, 24, 428-434. [CrossRef]

81. Zhu, Z.; Ren, X.; Chen, Z. Visual Tracking of Construction Jobsite Workforce and Equipment with Particle Filtering. J. Comput. Civ. Eng. 2016, 30. [CrossRef]

82. Zhu, Z.; Ren, X.; Chen, Z. Integrated Detection and Tracking of Workforce and Equipment from Construction Jobsite Videos. Autom. Constr. 2017, 81, 161-171. [CrossRef]

83. Bang, S.; Kim, H.; Kim, H. UAV-Based Automatic Generation of High-Resolution Panorama at a Construction Site with a Focus on Preprocessing for Image Stitching. Autom. Constr. 2017, 84, 70-80. [CrossRef]

84. Melo, R.R.S.; de Costa, D.B.; Álvares, J.S.; Irizarry, J. Applicability of Unmanned Aerial System (UAS) for Safety Inspection on Construction Sites. Saf. Sci. 2017, 98, 174-185. [CrossRef]

85. Torque Sensor-Power Tool Measurement. Available online: https://www.futek.com/applications/PowerTool-Measurement (accessed on 29 July 2020).

86. Bestard, G.A.; Sampaio, R.C.; Vargas, J.A.R.; Alfaro, S.C.A. Sensor Fusion to Estimate the Depth and Width of the Weld Bead in Real Time in GMAW Processes. Sensors 2018, 18, 962. [CrossRef]

87. Sensors for Construction Machinery-TM Automation Instruments Co., Ltd. Available online: https: //www.tmvenus.com/Sensors-For-Construction-Machinery-id3842075.html (accessed on 29 July 2020).

88. Temperature Sensor, China Temperature Sensor, Temperature Sensorr manufacturer-TM. Available online: https://www.tmvenus.com/Temperature-Sensor-pl3362865.html (accessed on 29 July 2020).

89. Gatti, U.C.; Schneider, S.; Migliaccio, G.C. Physiological Condition Monitoring of Construction Workers. Autom. Constr. 2014, 44, 227-233. [CrossRef]

90. Fang, Y.; Cho, Y.K.; Chen, J. A Framework for Real-Time pro-Active Safety Assistance for Mobile Crane Lifting Operations. Autom. Constr. 2016, 72, 367-379. [CrossRef]

91. Sztyler, T.; Stuckenschmidt, H. On-Body Localization of Wearable Devices: An Investigation of Position-Aware Activity Recognition. In Proceedings of the 2016 IEEE International Conference on Pervasive Computing and Communications, PerCom 2016, Sydney, NSW, Australia, 14-19 March 2016; pp. 1-9. [CrossRef]

92. Attal, F.; Mohammed, S.; Dedabrishvili, M.; Chamroukhi, F.; Oukhellou, L.; Amirat, Y. Physical Human Activity Recognition Using Wearable Sensors. Sensors 2015, 15, 31314-31338. [CrossRef]

93. Bao, L.; Intille, S.S. Activity Recognition from User-Annotated Acceleration Data. In Second International Conference, PERVASIVE 2004; Springer: Berlin/Heidelberg, Germany; New York, NY, USA,, 2004; pp. 1-17. [CrossRef]

94. Yang, K.; Jebelli, H.; Ahn, C.R.; Vuran, M.C. Threshold-Based Approach to Detect Near-Miss Falls of Iron-Workers Using Inertial Measurement Units. In Proceedings of the 2015 International Workshop on Computing in Civil Engineering, Austin, TX, USA, 21-23 June 2015; ASCE: Austin, TX, USA, 2015; pp. 148-155. [CrossRef]

95. Yang, K.; Ahn, C.R.; Vuran, M.C.; Aria, S.S. Semi-Supervised near-Miss Fall Detection for Ironworkers with a Wearable Inertial Measurement Unit. Autom. Constr. 2016, 68, 194-202. [CrossRef] 
96. Yi, W.; Chan, A.P.C. Critical Review of Labor Productivity Research in Construction Journals. J. Manag. Eng. 2014, 30, 214-225. [CrossRef]

97. El-Gohary, K.M.; Aziz, R.F.; Abdel-Khalek, H.A. Engineering Approach Using ANN to Improve and Predict Construction Labor Productivity under Different Influences. J. Constr. Eng. Manag. 2017, 143. [CrossRef]

98. Gilbreth, F.B. Motion Study: A Method for Increasing the Efficiency of the Workman; D. Van Nostrand Company: New York, NY, USA, 1911.

99. Guo, S.-J.; Tucker, R.L. Automation Needs Determination Using AHP Approach. Autom. Robot. Constr. X 1993, 39-46. [CrossRef]

100. Everett, J.G.; Slocum, A.H. Automation and Robotic Opportunities: Construction versus Manufacture. J. Constr. Eng. Manag. 1994, 120, 443-452. [CrossRef]

101. Ahmadt, A.N.B.; Scott, J.N.; Bradley, D.A. Task Decomposition in Support of Automation and Robotics in Construction. Autom. Robot. Constr. XII 1995, 407-414. [CrossRef]

102. Kisi, K.P.; Mani, N.; Rojas, E.M.; Foster, E.T. Optimal Productivity in Labor-Intensive Construction Operations: Pilot Study. J. Constr. Eng. Manag. 2017, 143. [CrossRef]

103. Hwang, B.G.; Shan, M.; Ong, J.J.M.; Krishnankutty, P. Mechanization in Building Construction Projects: Assessment and Views from the Practitioners. Prod. Plan. Control 2019, 31, 613-628. [CrossRef]

104. McKinsey. Reinventing Construction: A Route To Higher Productivity; McKinsey \& Company: Houston, TX, USA, 2017.

105. Bröchner, J.; Olofsson, T. Construction Productivity Measures for Innovation Projects. J. Constr. Eng. Manag. 2012, 138, 670-677. [CrossRef]

106. Park, H.-S.; Thomas Stephen, R.; Tucker Richard, L. Benchmarking of Construction Productivity. J. Constr. Eng. Manag. 2005, 131, 772-778. [CrossRef]

107. Nweke, H.F.; Teh, Y.W.; Al-garadi, M.A.; Alo, U.R. Deep Learning Algorithms for Human Activity Recognition Using Mobile and Wearable Sensor Networks: State of the Art and Research Challenges. Expert Syst. Appl. 2018, 105, 233-261. [CrossRef]

108. Nath, N.D.; Chaspari, T.; Behzadan, A.H. Automated Ergonomic Risk Monitoring Using Body-Mounted Sensors and Machine Learning. Adv. Eng. Inform. 2018, 38, 514-526. [CrossRef]

109. Meyers, F.E.; Stewart, J.R. Motion and Time Study for Lean Manufacturing, 3rd ed.; Prentice Hall: Upper Saddle River, NJ, USA, 2002.

110. Adrian, J.J. Construction Productivity: Measurement and Improvement; Stipes Publishing: Champaign, IL, USA, 2004.

111. CYPE. Generator of Prices for Construction. Available online: http://www.geradordeprecos.info/ (accessed on 10 October 2019).

112. Calvetti, D.; Magalhães, P.N.M.; Sujan, S.F.; Gonçalves, M.C.; Campos de Sousa, H.J. Challenges of Upgrading Craft Workforce into Construction 4.0-Framework and Agreements. Proc. Inst. Civ. Eng. Manag. Procure. Law 2020, 1-7. [CrossRef]

(C) 2020 by the authors. Licensee MDPI, Basel, Switzerland. This article is an open access article distributed under the terms and conditions of the Creative Commons Attribution (CC BY) license (http://creativecommons.org/licenses/by/4.0/). 